\title{
PENGEMBANGAN PERANGKAT PEMBELAJARAN IPA SMP BERBASIS PENDEKATAN SAINTIFIK DENGAN MODEL PEMBELAJARAN INKUIRI TERBIMBING
}

\author{
Rohmatus Syafi'ah'), Tukiran²), Fida Rachmadiarti³) \\ ${ }^{1)}$ Mahasiswa Program Studi Pendidikan Sains, Program Pascasarjana Universitas Negeri Surabaya \\ ${ }^{2), 3)}$ Dosen Pascasarjana Prodi Pendidikan Sains Univesrtitas Negeri Surabaya \\ E-mail: rohmatus.syafi@yahoo.com
}

\begin{abstract}
This research aimed to describe the teaching material's feasibility of IPA based on scientific approach with guided inquiry learning model. This research had been done in three phases, that are creating the teaching material's, validating and doing revision, and verifying them at learning activity in class with one group pretest-posttest design. Techniques for collecting data was conducted through questionnaires, validation, observation, and test. Techniques for analyzing data used descriptive qualitative. The result of research showed that (1) the feasibility of teaching material's based on scientific approach with guided inquiry learning model of IPA that consist of syllabus, lesson plan, student book, student worksheet and the learning outcome test gained $4.89 ; 4.72 ; 4.81 ; 4.79$; and 4.51 respectively that are categorized as valid. (2) The implementation of this lesson plan at two meetings in VII-A and VII-B class is categorized as good with average minimal scores 4.00 and got $94 \%$ in minimal percentage of agreement aspect; (3) Working in a group was the most dominant student activity at two meetings at VII-A and VII-B classes with average frequency of two meetings, observed are 19 and 10 times (VII-A class), and 18 and 10 times (VII-B class); (4) The learning outcomes that can be analyzed by calculating classical masteries at the first and second meetings on multiple choice and essay are 95.5\%; 100\%; 91\%; 95\% (VII-A class); and 91\%; 86\%; 91\%; and 91\% (VII-B class) respectively, and (5) Students gave the positive response to the learning process using teaching material's of IPA based on scientific approach with guided inquiry model with average score to be 3.3 (VII-A class) and 3.4 (VII-B class). Based on the result of the analyzed data, it can be concluded that the teaching material's of IPA based on scientific approach with guided inquiry model which had been developed was feasible to be used.
\end{abstract}

\section{Keywords: Guided Inquiry Learning, Scientific Approach, Teaching Material's}

\begin{abstract}
Abstrak: Tujuan penelitian ini untuk mendeskripsikan kelayakan perangkat pembelajaran IPA SMP berbasis pendekatan saintifik dengan model pembelajaran inkuiri terbimbing. Penelitian ini dilaksanakan dalam tiga tahap, yaitu tahap mengembangkan perangkat pembelajaran, tahap validasi dan revisi, dan tahap uji coba dalam pembelajaran di kelas dengan menggunakan rancangan one group pretest-posttest design. Teknik pengumpulan data dengan angket, validasi, pengamatan, dan tes. Teknik analisis data menggunakan deskriptif kualitatif. Hasil penelitian menunjukkan bahwa: (1) Kelayakan perangkat pembelajaran yang terdiri dari silabus, RPP, buku siswa, LKS, dan tes hasil belajar masing-masing diperoleh hasil 4,89; 4,72; 4,81; 4,79; dan 4,51 dengan kriteria valid. (2) Keterlaksanaan RPP pada dua pertemuan di kelas VII-A dan VII-B mendapatkan kriteria baik dengan skor rata-rata minimal 4,00 dan rata-rata persentase kesepakatan antara dua pengamat minimal 94\%; (3) Frekuensi aktivitas siswa yang paling dominan pada dua pertemuan di kelas VII-A dan VII-B adalah bekerja dalam kelompok dengan frekuensi pengamatan rata-rata pada kedua pertemuan berturut-turut 19 dan 10 kali (kelas VII-A), dan 18 dan 10 kali (kelas VII-B) (4) Hasil belajar siswa yang dilihat dari ketuntasan klasikal pada pertemuan pertama dan kedua pada soal PG dan uraian berturut-turut sebesar 95,5\%; 100\%; 91\%; 95\% (kelas VII-A); dan 91\%; 86\%; 91\%; dan 91\% (kelas VII-B), dan (5) Respon positif siswa terhadap pembelajaran IPA berbasis pendekatan saintifik dengan model pembelajaran inkuiri terbimbing dengan nilai rata-rata 3,3 (kelas VII-A) dan 3,4 (kelas VII-B). Berdasarkan hasil analisis data, diperoleh kesimpulan bahwa perangkat pembelajaran IPA berbasis pendekatan saintifik dengan model pembelajaran inkuiri terbimbing yang telah dikembangkan layak untuk digunakan.
\end{abstract}

Kata kunci: Model Pembelajaran Inkuiri Terbimbing, Pendekatan Saintifik, Perangkat Pembelajaran.

\section{PENDAHULUAN}

Kurikulum adalah rancangan pendidikan yang memberi kesempatan siswa untuk mengembangkan potensi dirinya dalam suatu suasana belajar yang menyenangkan dan sesuai dengan kemampuan dirinya untuk memiliki kualitas yang diinginkan masyarakat dan bangsa. Kurikulum merupakan salah satu unsur yang dapat memberikan kontribusi yang signifikan untuk mewujudkan proses berkembangnya kualitas potensi siswa. Pengembangan dan pelaksanaan kurikulum berbasis kompetensi merupakan salah satu strategi pembangunan pendidikan nasional sebagaimana yang diamanatkan dalam Undang-Undang Nomor 20 Tahun 2003 tentang Sistem Pendidikan Nasional 
(Kemendikbud, 2013). Kurikulum terus mengalami perkembangan dan penyempurnaan seiring dengan adanya perkembangan IPTEK. Pemerintah saat ini menetapkan suatu kurikulum baru yaitu Kurikulum 2013 sebagai hasil dari perkembangan Kurikulum Tingkat Satuan Pendidikan (KTSP). Meskipun demikian, pelaksanaan Kurikulum 2013 belum dapat terlaksana secara merata di seluruh satuanh pendidikan yang ada di Indonesia. Misalnya saja di kota Tulungagung, dari sekian banyak SMP/ MTs di Tulungagung hanya ada enam SMP yang ditunjuk sebagai sekolah sasaran diterapkannya Kurikulum 2013 salah satunya adalah SMPN 2 KarangrejoTulungagung.

Berdasarkan hasil wawancara dengan guru IPA kelas VII SMPN 2 Karangrejo-Tulungagung diperoleh informasi bahwa, SMPN ini merupakan salah satu dari enam sekolah yang ditunjuk oleh Dinas Pendidikan setempat sebagai sekolah sasaran diterapkannya Kurikulum 2013. Enam SMP yang ditunjuk sebagai sekolah sasaran penerapan Kurikulum 2013 sengaja diambil dari latar belakang sekolah yang berbeda-beda. Hal ini bertujuan untuk mengetahui sejauh mana keberhasilan penerapan Kurikulum 2013, jika diterapkan pada sekolah yang kemampuan siswanya tergolong rendah dan fasilitas sekolah yang belum memadai dibandingkan dengan sekolah yang kemampuan siswanya baik dan fasilitas sekolah yang memadai, dengan harapan penerapan Kurikulum 2013 ini nantinya dapat terlaksana dengan baik di seluruh sekolah yang ada di Indonesia mulai dari daerah pelosok sampai perkotaan.

Guru di SMPN 2 Karangrejo-Tulungagung khususnya guru mata pelajaran IPA kelas VII, sudah mendapatkan sosialisasi dan pelatihan khusus tentang Kurikulum 2013. Sosialisasi dan pelatihan yang mereka dapatkan antara lain adalah tentang penyusunan perangkat pembelajaran berbasis Kurikulum 2013 dan penerapan pembelajaran saintifik. Pada kenyataannya walaupun sudah mendapatkan sosialisasi mengenai Kurikulum 2013, mereka mengatakan masih banyak menemukan kesulitan dalam menerapkan Kurikulum 2013 tersebut. Hal ini dikarenakan sarana dan prasarana sekolah yang kurang memadai (misalnya peralatan laboratorium IPA) dan kemampuan siswa yang rendah. Guru IPA juga mengatakan bahwa masih merasa kesulitan dalam menyusun perangkat pembelajaran berbasis Kurikulum 2013 sehingga guru jarang menyiapkan perangkat pembelajaran sebelum melaksanakan kegiatan belajar mengajar. Selain itu, sampai saat ini buku siswa yang telah disediakan oleh Dinas Pendidikan kabupaten Tulungagung juga belum memadai dan sekolah terpaksa meminjamkan satu buku untuk dua sampai tiga orang siswa.

Guru IPA juga jarang sekali bahkan hampir tidak pernah menerapkan model pembelajaran berbasis masalah, model pembelajaran berbasis proyek, ataupun model pembelajaran inkuiri seperti yang diamanatkan dalam Kurikulum 2013 dikarenakan fasilitas dan kemampuan siwa yang dirasa kurang mendukung untuk diterapkannya model-model pembelajaran tersebut. Tidak pernah diterapkannya model-model pembelajaran sesuai yang diamanatkan dalam Kurikulum 2013 tersebut juga dikarenakan guru masih merasa kesulitan dalam menyusun perangkat pembelajaran walaupun sudah diberikan sosialisai dan pelatihan. Menurut guru IPA, banyak yang harus dipelajari dan masih perlu wawasan yang lebih luas lagi untuk benar-benar menerapkan pembelajaran sesuai yang diamanatkan dalam Kurikulum 2013. Kenyataannya walaupun dikatakan sudah menerapkan Kurikulum 2013, pembelajaran IPA yang berlangsung di kelas VII SMPN Karangrejo-Tulungagung masih berlangsung satu arah (teacher centered). Proses pembelajaran di kelas masih menggunakan metode pembelajaran seperti ceramah, dan pemberian tugas dalam setiap pembelajaran. Hal ini didukung dengan data angket yang telah disebarkan pada 15 siswa kelas VII SMPN 2 Karangrejo-Tulungagung, yang menunjukkan bahwa 90\% siswa menyatakan bahwa kegiatan pembelajaran IPA yang sering dilakukan di sekolah berupa penjelasan teori di dalam kelas dan metode yang paling sering digunakan guru dalam mengajar IPA adalah metode pemberian tugas. Hal ini mengakibatkan pembelajaran IPA di dalam kelas terkesan monoton dan membosankan sehingga mempengaruhi hasil belajar siswa.

Guru IPA kelas VII jarang sekali mengajak siswanya melakukan kegiatan praktikum. Mereka menyatakan bahwa dari sekian banyak materi pembelajaran IPA di kelas VII, siswa hanya dua kali melakukan kegiatan yaitu pada materi pengukuran dan klasifikasi makhluk hidup, sedangkan untuk materi IPA lainnya hanya dijelaskan secara teori. Padahal sesuai amanat dalam Kurikulum 2013, dalam proses pembelajaran siswa harus memiliki lima pengalaman belajar pokok yaitu mengamati, menanya, mengumpulkan informasi, mengasosiasi atau menganalisis, dan mengkomunikasikan apa yang sudah ditemukannya dalam kegiatan analisis. Lima pengalaman belajar pokok tersebut salah satunya dapat diperoleh jika siswa terlibat langsung dalam proses pembelajaran melalui kegiatan praktikum dalam pembelajaran IPA. Pernyataan guru IPA tersebut didukung dengan data angket yang menunjukkan bahwa $70 \%$ siswa menyatakan bahwa kegiatan pembelajaran IPA yang sering dilakukan adalah penjelasan teori dan $80 \%$ siswa menyatakan selama ini pembelajaran IPA tidak pernah dilakukan kegiatan praktikum. Hal ini mengakibatkan siswa merasa kesulitan dan bosan 
terhadap beberapa materi yang mereka anggap sulit diantaranya adalah materi klasifikasi materi dan materi larutan (asam, basa, dan garam), sehingga menyebabkan hasil belajar mereka tergolong dalam kategori cukup dan kurang. Faktor lain yang menjadi penyebab hasil belajar siswa tergolong dalam kategori cukup dan kurang adalah siswa kurang memperhatikan penjelasan guru dan kurang aktif dalam mengikuti kegiatan pembelajaran di dalam kelas.

Banyaknya siswa yang merasa bosan dan kurang tertarik terhadap penjelasan guru, lebih disebabkan oleh metode pembelajaran yang sering digunakan kurang menggugah motivasi belajar siswa. Pemilihan metode yang kurang tepat dalam proses pembelajaran tentu dapat menimbulkan kejenuhan bagi siswa dan motivasi belajar menjadi kurang. Anak-anak yang kurang termotivasi belajar ini biasanya cenderung tidak memperhatikan penjelasan guru, sehingga pemahaman konsep mereka menjadi rendah. Oleh karena itu, untuk memaksimalkan daya serap dan pemahaman siswa dalam menerima pelajaran dibutuhkan cara belajar yang melibatkan interaksi siswa secara langsung seperti yang diamanatkan dalam Kurikulum 2013 bahwa dalam pembelajaran harus ada esensi pendekatan ilmiah atau pendekatan saintifik (scientific approach).

Pembelajaran dengan pendekatan saintifik adalah proses pembelajaran yang dirancang sedemikian rupa agar siswa secara aktif mengkonstruk atau membangun konsep, hukum atau prinsip melalui tahapan-tahapan mengamati (untuk mengidentifikasi atau menemukan masalah), merumuskan masalah, mengajukan atau merumuskan hipotesis, mengumpulkan data dengan berbagai teknik, menganalisis data, menarik kesimpulan dan mengomunikasikan konsep, hukum atau prinsip yang ditemukan (Anonim, 2013). Pendekatan saintifik dimaksudkan untuk memberikan pemahaman siswa dalam mengenal, memahami berbagai materi menggunakan pendekatan ilmiah, informasi dapat berasal dari mana saja, kapan saja, tidak bergantung pada informasi searah dari guru. Oleh karena itu kondisi pembelajaran yang diharapkan diarahkan untuk mendorong siswa dalam mencari tahu dari berbagai sumber melalui observasi, dan bukan hanya sekedar menerima penjelasan dari guru saja.

Pendekatan saintifik dalam pembelajaran melibatkan keterampilan proses seperti mengamati, mengklasifikasi, mengukur, meramalkan, menjelaskan, dan menyimpulkan. Siswa berperan sebagai subjek belajar yang dilibatkan secara aktif dalam proses pembelajaran dan guru hanyalah seorang fasilitator yang membimbing dan mengkoordinasikan kegiatan belajar siswa. Pembelajaran lebih menekankan pada proses pencarian pengetahuan dari pada transfer pengetahuan. Pembelajaran saintifik mengajak siswa untuk melakukan proses pencarian pengetahuan berkenaan dengan materi pelajaran melalui berbagai aktivitas proses sains. Siswa diarahkan untuk menemukan sendiri berbagai fakta, membangun konsep, dan nilai-nilai baru yang diperlukan untuk kehidupannya. Siswa dididik dan dilatih untuk terampil dalam memperoleh dan mengolah informasi melalui aktivitas berpikir dengan mengikuti prosedur (metode) ilmiah, seperti terampil melakukan pengamatan, pengukuran, pengklasifikasian, penarikan kesimpulan, dan pengkomunikasian hasil temuan.

Pendekatan saintifik dirasa tepat untuk diterapkan dalam proses pembelajaran karena sesuai dengan karakteristik pembelajaran IPA. IPA merupakan ilmu yang pokok bahasannya adalah alam dan segala isinya, pengetahuan yang sistematis dan tersusun secara teratur, berlaku umum, serta merupakan kumpulan data observasi dan eksperimen (Depdiknas, 2006). Siswa diarahkan untuk membandingkan hasil prediksi siswa dengan teori melalui kegiatan eksperimen dengan menggunakan metode ilmiah dalam belajar IPA sesuai dengan maksud diterapkannya pendekatan saintifik dalam proses pembelajaran.

Peneliti memilih model pembelajaran inkuiri terbimbing dalam proses pembelajaran IPA materi larutan asam, basa, dan garam karena berdasarkan karakteristik materi tersebut, akan lebih tepat jika siswa mempunyai gambaran yang jelas terhadap pelajaran. Pemahaman materi oleh siswa akan lebih bermakna jika dalam proses pembelajarannya berpusat pada siswa. Model pembelajaran dimana dalam proses pembelajarannya berpusat pada siswa antara lain adalah cooperative learning, problem based learning, inkuiri terbimbing (guided inquiry), dan sebagainya. Modelmodel pembelajaran tersebut mempunyai karakteristik dengan kelebihan masing-masing, namun yang paling sesuai dengan karakteristik materi larutan asam, basa, dan garam, serta sesuai dengan tuntutan pembelajaran Kurikulum 2013 adalah model pembelajaran inkuiri terbimbing.

Berdasarkan hasil penelitian yang dilakukan oleh Bilgin (2009) menyebutkan bahwa siswa dengan kelompok inkuiri terbimbing yang belajar secara kooperatif mempunyai pemahaman yang lebih baik terhadap penguasaan konsep materi pelajaran dan menunjukkan sikap yang positif. Penelitian lain yang senada juga diungkapkan oleh Khoiroh (2013) bahwa pembelajaran inkuiri terbimbing pada pokok bahasan asam, basa, dan garam dapat meningkatkan penguasaan konsep dan keterampilan berpikir kritis siswa serta terdapat hubungan positif yang kuat dan signifikan antara penguasaan konsep dengan keterampilan berpikir kritis siswa setelah pelaksanaan pembelajaran inkuiri terbimbing.

Penelitian ini dilakukan untuk mengembangkan perangkat pembelajaran IPA SMP berbasis pendekatan 
saintifik dengan model pembelajaran inkuiri terbimbing untuk memfasilitasi pembelajaran yang relevan dengan tuntutan perubahan tersebut $\mathrm{di}$ atas. Perangkat pembelajaran ini dikembangkan untuk memberdayakan siswa dan guru dalam proses pembelajaran, dirancang dengan mengacu pada teori yang ada, serta hasil penelitian lapangan yang telah diperoleh sehingga diharapkan dapat tercapai keberhasilan dalam proses pembelajaran.

\section{METODE PENELITIAN}

Penelitian yang dilakukan termasuk jenis penelitian pengembangan yang didahului dengan penyusunan perangkat pembelajaran. Uji coba perangkat pembelajaran IPA SMP berbasis pendekatan saintifik dengan model pembelajaran inkuiri terbimbing menggunakan desain penelitian one-group pretestpostest design. Penelitian dilakukan untuk mengetahui hasil pengembangan perangkat pembelajaran IPA SMP berbasis pendekatan saintifik dengan model pembelajaran inkuiri terbimbing dan hasil uji coba perangkat pembelajaran tersebut di dalam kelas. Perangkat pembelajaran yang disusun berupa silabus, Rencana Pelaksanaan Pembelajaran (RPP), Lembar Kegiatan Siswa (LKS), buku siswa, dan tes hasil belajar materi asam basa pada siswa kelas VII SMP. Perangkat pembelajaran tersebut selanjutnya divalidasi oleh pakar dan praktisi pendidikan sebelum diujicobakan di kelas.

Subyek dalam penelitian ini adalah perangkat pembelajaran IPA SMP berbasis pendekatan saintifik dengan model pembelajaran inkuiri terbimbing. Penelitian dilaksanakan pada semester gasal tahun ajaran 2014/2015 tanggal 10 sampai dengan 15 November 2014 pada 44 siswa kelas VII SMP Negeri 2 Karangrejo-Tulungagung. Instrumen yang digunakan dalam pengumpulan data terdiri dari lembar validasi perangkat pembelajaran, lembar angket respons siswa terhadap buku siswa dan LKS, lembar penilaian keterlaksanaan RPP, lembar pengamatan aktivitas siswa, angket respon siswa terhadap pembelajaran, dan lembar penilaian tes hasil belajar.

Data hasil validasi perangkat pembelajaran, respons siswa terhadap buku siswa dan LKS pengamatan keterlaksanaan RPP, aktivitas siswa, respon siswa terhadap pembelajaran, dan hasil belajar siswa dianalisis secara deskriptif kualitatif.

\section{HASIL PENELITIAN DAN DISKUSI}

\section{A. Validitas Perangkat Pembelajaran}

Hasil validasi perangkat pembelajaran meliputi silabus, RPP, buku siswa, LKS, dan tes hasil belajar diperoleh skor rata-rata masing-masing adalah 4,89; 4,$72 ; 4,81 ; 4,79$; dan 4,51 dengan kategori valid, dengan demikian perangkat pembelajaran yang dikembangkan layak digunakan dalam pembelajaran.
B. Respons Siswa terhadap Buku Siswa dan LKS

Hasil angket respons siswa terhadap buku siswa dan LKS asam basa pada siswa kelas VII-A dan VII-B SMPN 2 Karangrejo-Tulungagung digambarkan masing-masing seperti Gambar 1, 2, 3 dan 4.

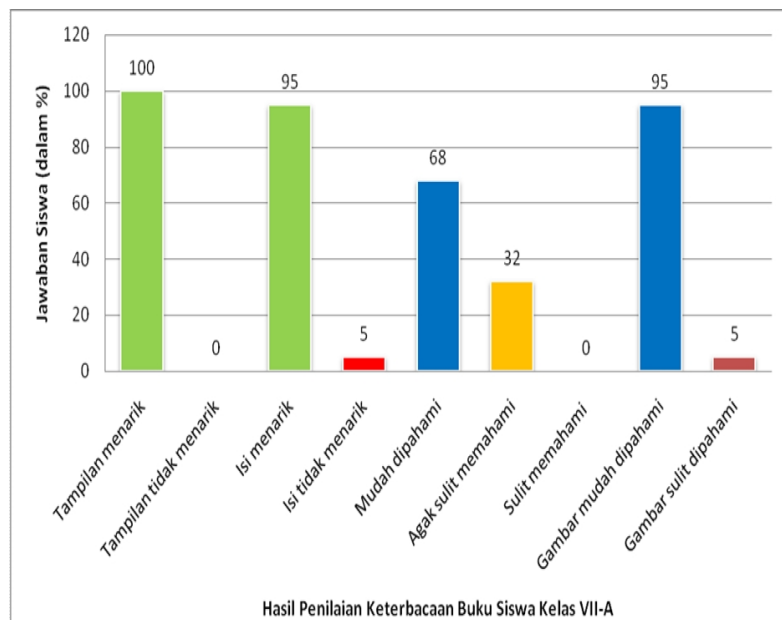

Gambar 1. Persentase Respons Siswa terhadap Buku Siswa di Kelas VII-A

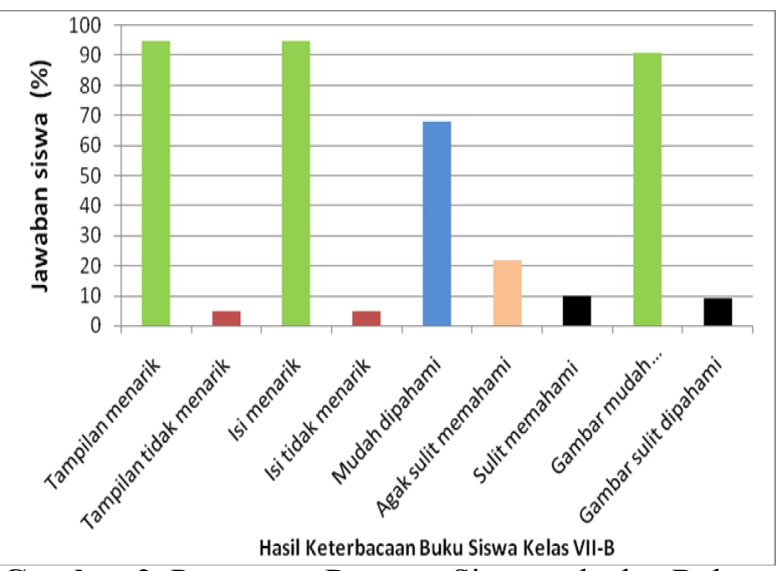

Gambar 2. Persentase Respons Siswa terhadap Buku Siswa di Kelas VII-B

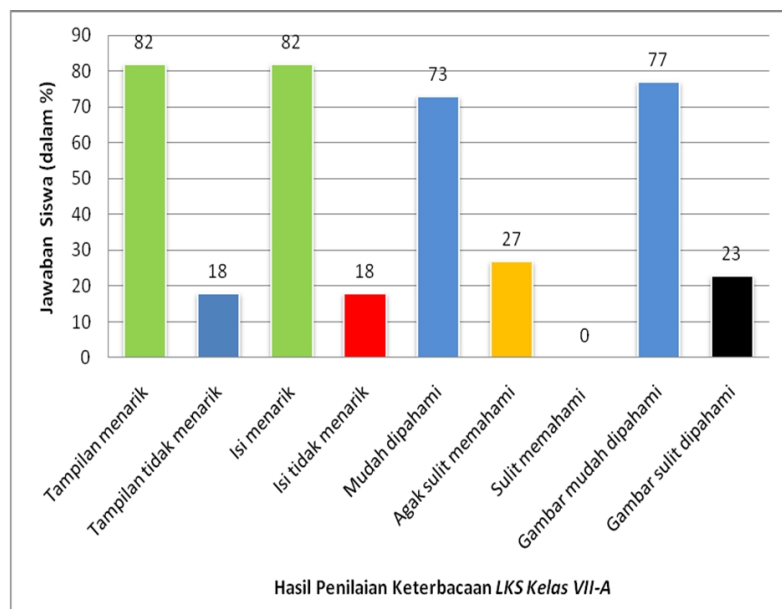

Gambar 3 Persentase Penilaian Respons Siswa terhadap LKS di Kelas VII-A 


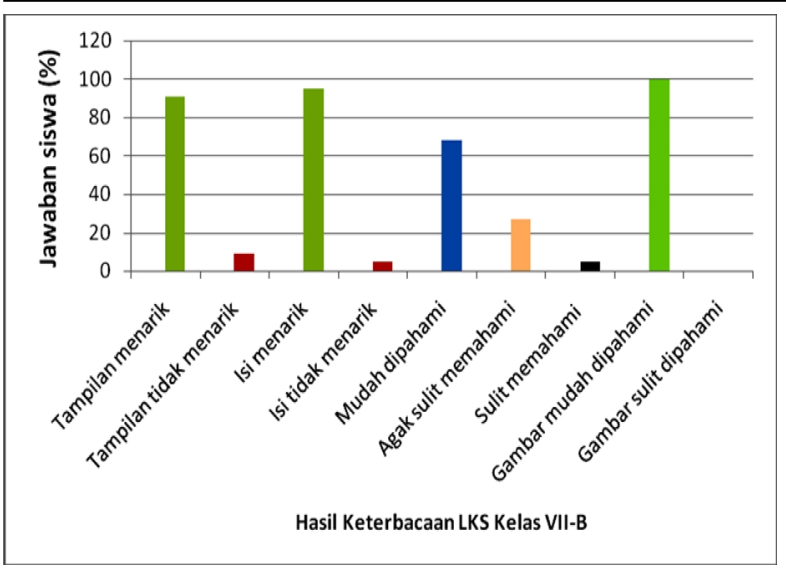

Gambar 4. Persentase Penilaian Respons Siswa terhadap LKS di Kelas VII-B

\section{Keterlaksanaan RPP}

Pengamatan terhadap keterlaksanaan RPP dalam pembelajaran IPA berbasis saintifik dengan model pembelajaran inkuiri terbimbing dilakukan oleh dua pengamat. Pengamatan dilakukan pada dua kali pertemuan. Dengan skor rata-rata pengamat untuk kedua pertemuan sebesar 4,11 dan persentase kesepakatan (percentage of agreement) antara dua pengamat sebesar 94,5\%. Secara umum keterlaksanaan RPP berkategori baik dan instrumen keterlaksanaan RPP layak digunakan.

\section{Aktivitas Siswa}

Berdasarkan seluruh aspek aktivitas siswa yang telah diamati diperoleh persentase kesepakatan (percentage of agreement) rata-rata pada pertemuan 1 dan 2 berturut-turut antara dua pengamat di kelas VII-A sebesar 91\% dan 95,2\%, sedangkan di kelas VII-B sebesar $87,1 \%$ dan 93,5\%. Hal ini menunjukkan bahwa terdapat kejelasan dan kesepahaman antara kedua pengamat, sehingga dapat disimpulkan bahwa instrumen penilaian aktivitas siswa layak digunakan.. Data selanjutnya disajikan dalam bentuk diagram seperti pada Gambar 5, 6, 7 dan 8 .

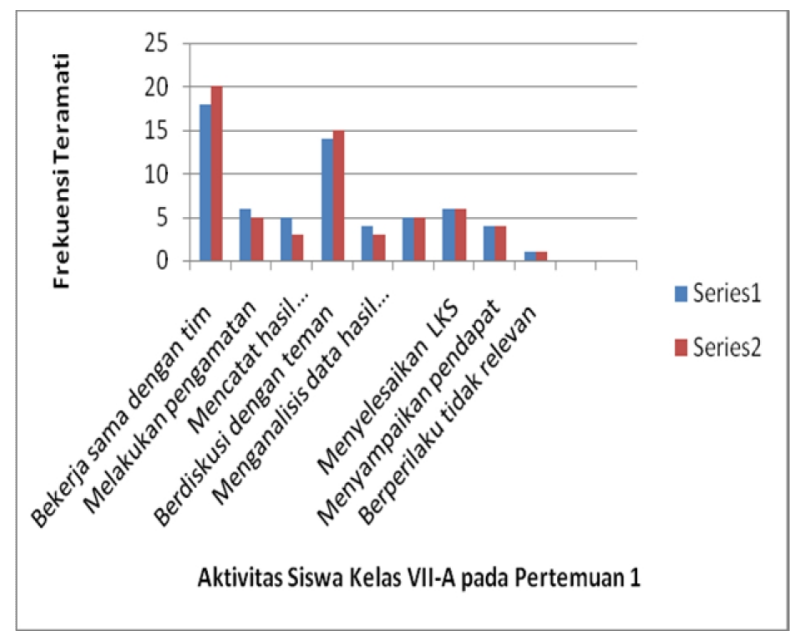

Gambar 5. Aktivitas Siswa Kelas VII-A pada Pertemuan 1

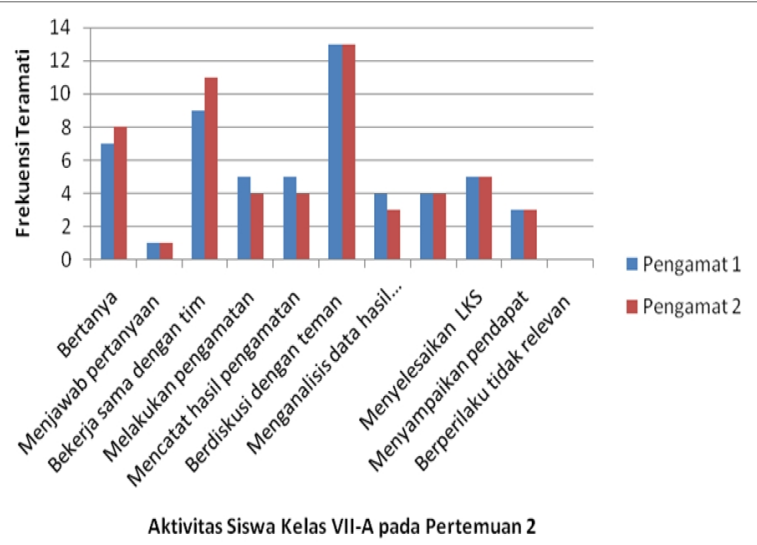

Gambar 6. Aktivitas Siswa Kelas VII-A pada Pertemuan 2

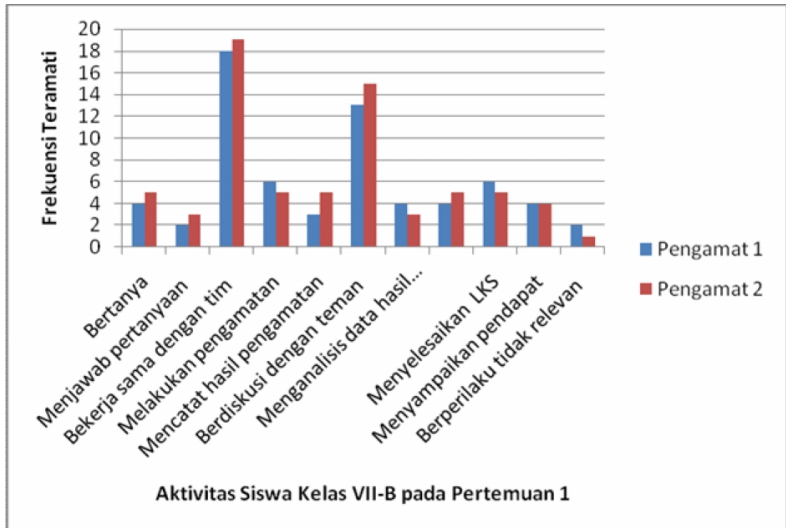

Gambar 7. Aktivitas Siswa Kelas VII-B pada Pertemuan 1

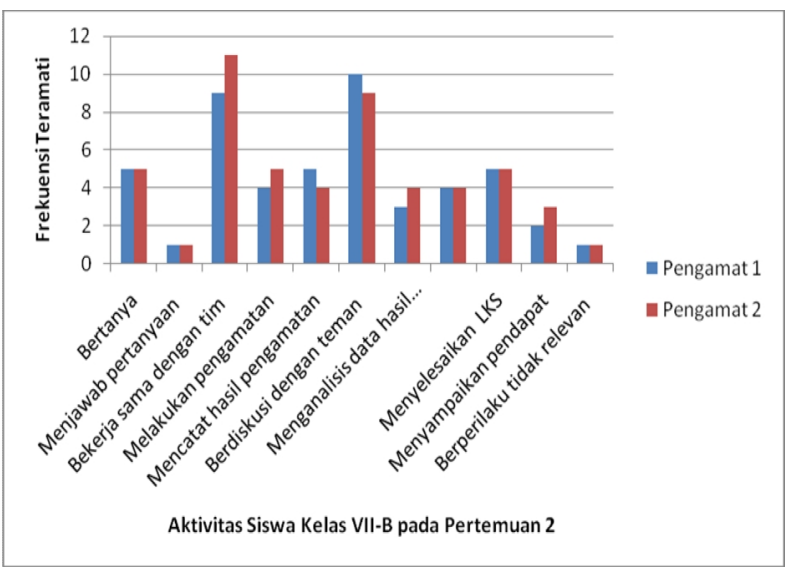

Gambar 8. Aktivitas Siswa Kelas VII-B pada Pertemuan 2

Aktivitas siswa yang diamati merupakan serangkaian kegiatan siswa selama proses pembelajaran berlangsung. Hasil analisis aktivitas siswa menunjukkan bahwa aktivitas yang paling dominan dilakukan oleh siswa pada pertemuan 1 dan 2 di kelas VII-A dan VII-B yaitu bekerja dalam kelompok dengan frekuensi pengamatan rata-rata pada kedua pertemuan secara berturut-turut untuk sebesar 19 dan 10 untuk kelas VII-A, dan 18 dan 10 untuk kelas VII-B. 
Frekuensi lebih rendah berikutnya adalah berdiskusi dengan teman sekelompok. Hal ini dikarenakan siswa pada fase merencanakan pemecahan masalah sampai analisis data sudah membentuk kelompok untuk berdiskusi, melakukan pengamatan, melakukan analisis data, dan mengkomunikasikan hasil pengamatan, sehingga frekuensi dua aktivitas siswa tersebut lebih dominan dari yang lainnya. Aktivitas ini berperan dalam peningkatan penguasaan konsep, karena tutor teman sebaya dalam kelompok akan melibatkan siswa dalam pembelajaran yang aktif, seorang siswa mengajar siswa yang lain, dan memungkinkan guru untuk membimbing serta memantau pembelajaran di kelas, tutorial teman sebaya sering memberikan manfaat pada prestasi siswa (Nur, 2011).

\section{E. Hasil Belajar Siswa}

Tes hasil belajar siswa terdiri dari pretest dan posttest dengan soal yang sama pada materi larutan asam, basa, dan garam sebanyak 10 butir soal pilihan ganda dan 5 soal essay. Dalam proses pembelajaran, siswa menggunakan buku siswa dan LKS berbasis pendekatan saintifik dengan model pembelajaran inkuiri terbimbing, diperoleh hasil belajar yang meningkat dengan skor peningkatan mulai kategori sedang $(0,5)$ sampai tinggi $(1,0)$, seperti yang pada Gambar 9, 10, 11, dan 12.

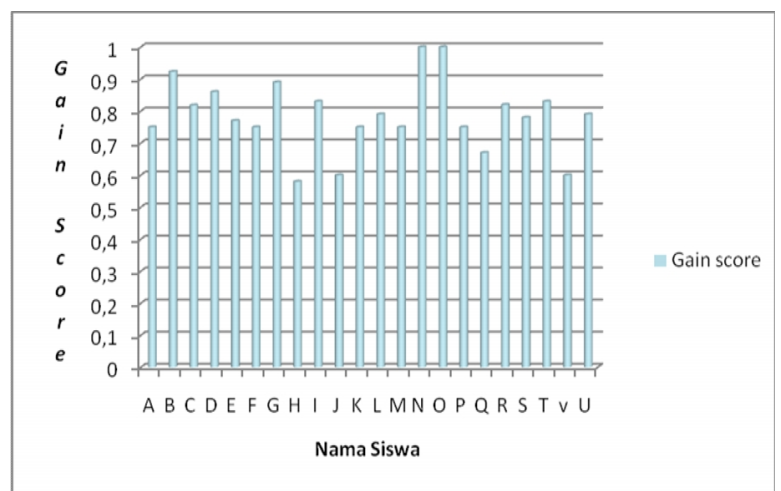

Gambar 9. Gain Score Kompetensi Pengetahuan Soal PG Kelas VII-A

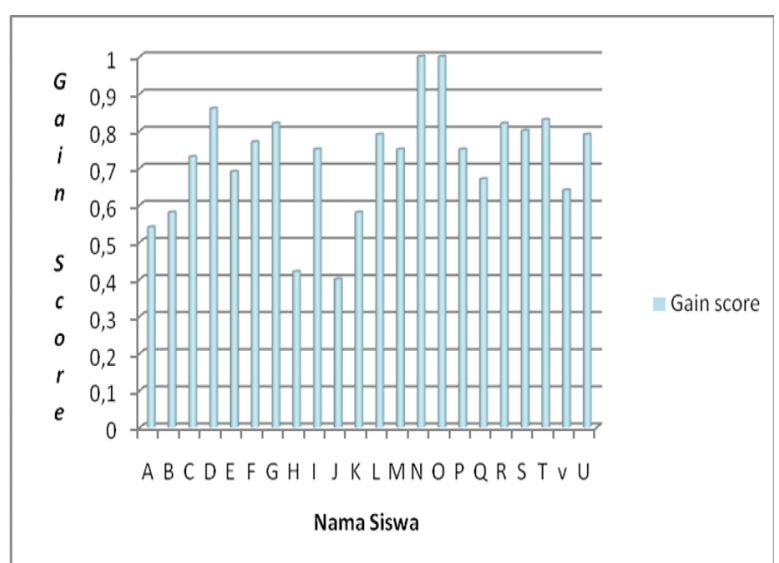

Gambar 10. Gain Score Kompetensi Pengetahuan Soal PG Kelas VII-B

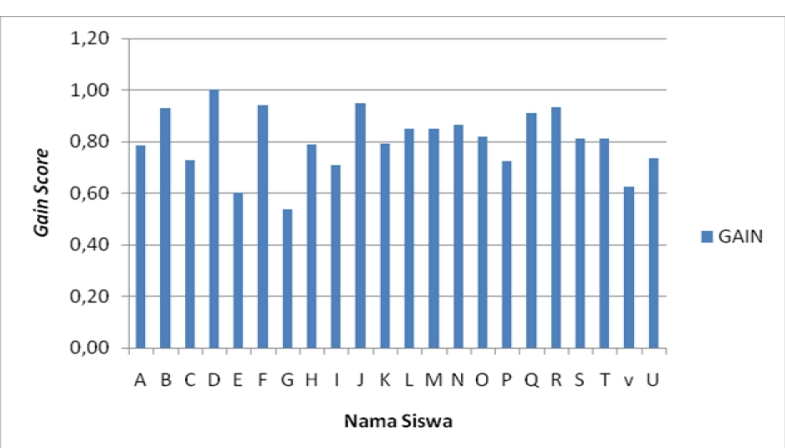

Gambar 11. Gain Score Kompetensi Pengetahuan Soal Essay Kelas VII-A

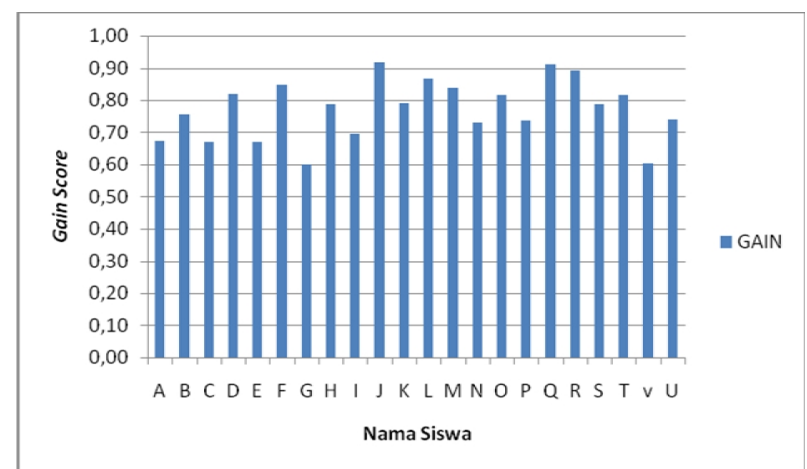

Gambar 12. Gain Score Kompetensi Pengetahuan Soal Essay Kelas VII-B

Data skor peningkatan (gain score) juga didukung oleh hasil analisis sensitivitas butir soal yang menunjukkan indeks sensitivitas terendah 0,3 . Hal ini menunjukkan bahwa butir soal tes hasil belajar yang digunakan memiliki kepekaan yang cukup terhadap efek-efek pembelajaran.

Secara keseluruhan ketuntasan indikator rata-rata pada pertemuan satu dan dua termasuk kategori tuntas dengan persentase minimal $75 \%$ dan persentase maksimal $100 \%$. Hal ini menunjukkan bahwa tes hasil belajar pada kompetensi pengetahuan yang dikembangkan baik/layak digunakan untuk mengukur ketercapaian indikator kompetensi pengetahuan. Selain itu, ketuntasan indikator yang juga diikuti dengan ketuntasan individual dan ketuntasan klasikal siswa juga menunjukkan bahwa melalui tahapan-tahapan pendekatan saintifik dan model pembelajaran inkuiri terbimbing dalam proses pembelajaran membantu siswa dalam meningkatkan pemahaman konsep terkait materi yang sedang dipelajari. Dengan menjawab pertanyaan pengayaan yang terstruktur dalam LKS, merumuskan pertanyaan, memberikan jawaban sementara, melakukan analisis data, dan menarik kesimpulan berdasarkan data hasil pengamatan melalui kegiatan diskusi dengan teman sekelompok, siswa termotivasi untuk berkomunikasi dan terlibat aktif dalam kegiatan pembelajaran. Hal tersebut akan membantu siswa dalam memperoleh pengalaman belajar. Dengan pengalaman tersebut, perilaku, pengetahuan, dan 
keterampilan siswa akan menjadi lebih baik sehingga hasil belajar siswa meningkat.

Hal tersebut di atas sesuai dengan pandangan teori konstruktivisme yang menyatakan bahwa perkembangan kognitif merupakan suatu proses dimana anak secara aktif membangun sistem arti dan pemahaman terhadap realita melalui pengalaman dan interaksi mereka (Arends, 2008). Berdasarkan hasil penelitian yang dilakukan oleh Hidayati (2014) disimpulkan bahwa dengan pendekatan ilmiah dapat meningkatkan hasil belajar siswa pada standar kompetensi mengoperasikan sistem kendali elektromagnetik. Penelitian lain yang senada juga diungkap oleh Machin (2014) yang menyimpulkan bahwa penerapan pendekatan saintifik berpengaruh positif terhadap hasil belajar kognitif, afektif dan psikomotorik serta telah mencapai ketuntasan klasikal yang ditetapkan, yakni lebih dari $85 \%$ dari seluruh siswa yang mengikuti pembelajaran.

\section{F. Respon Siswa}

Responden (siswa) diminta untuk membaca pernyataan yang disajikan dan memberi respon dengan cara memilih salah satu kategori yang sesuai dengan menggunakan skala Likert. Hasil analisis disajikan dalam bentuk diagram pada Gambar 13 dan 14.

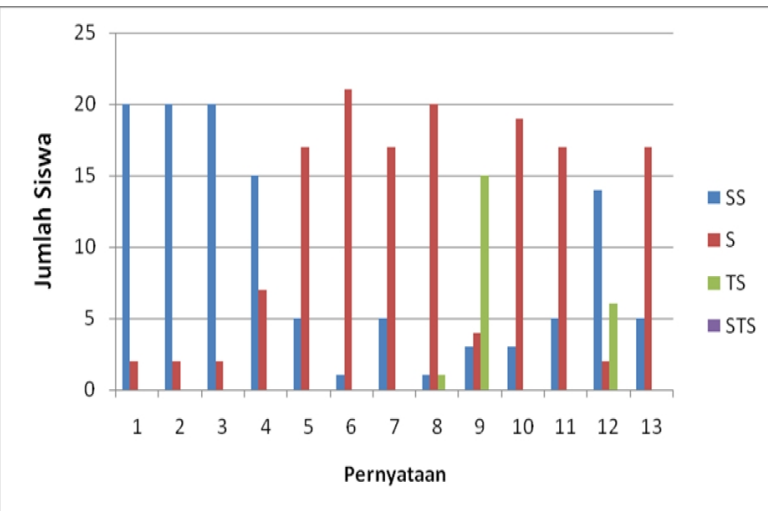

Gambar 13 Respon Siswa Kelas VII-A terhadap Pembelajaran IPA Berbasis Pendekatan Saintifik

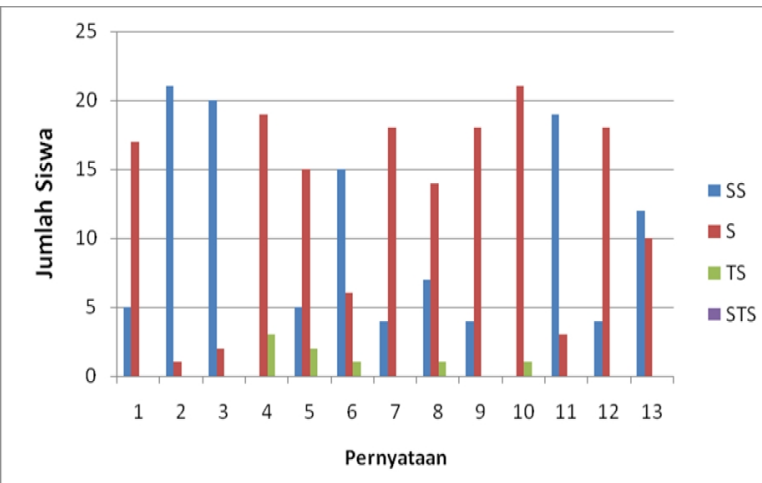

Gambar 14. Respon Siswa Kelas VII-B terhadap Pembelajaran IPA Berbasis Pendekatan Saintifik
Hasil anlaisis respons siswa terhadap pembelajaran menunjukkan bahwa 20 siswa menyatakan sangat setuju dan 2 siswa menyatakan setuju dan termotivasi dalam proses pembelajaran IPA berbasis pendekatan saintifik. Hal ini sesuai dengan hasil analisis keterlaksaaan RPP, karena siswa termotivasi dengan baik dalam proses pembelajaran maka RPP juga dapat terlaksana dengan baik, sehingga skor rata-rata keterlaksanaan RPP sebesar 4,22 dengan kategori baik; 15 siswa sangat setuju dan 8 siswa setuju (kelas VII-A), serta 19 siswa kelas VII-B setuju bahwa pembelajaran IPA berbasis pendekatan saintifik dengan model pembelajaran inkuiri terbimbing membuat siswa lebih aktif, karena model pembelajaran tersebut berpusat pada siswa sehingga menjadikan siswa lebih aktif daripada pembelajaran yang berpusat pada guru.

Sebanyak satu siswa sangat setuju dan 21 siswa setuju (kelas VII-A), dan 15 siswa sangat setuju dan 6 siswa setuju (kelas VII-B) bahwa mereka lebih bisa mengemukakan pendapat dalam diskusi; 20 siswa sangat setuju dan 2 siswa setuju (kelas VII-A), serta 21 siswa sangat setuju dan 1 siswa setuju (kelas VII-B) bahwa pembelajaran berbasis pendekatan saintifik menarik dan menyenangkan karena banyak disertai kegiatan pengamatan atau eksperimen. Hal tersebut dapat membuat siswa lebih aktif dan termotivasi untuk mempelajari materi asam, basa, dan garam karena dapat mengaplikasikan teori secara langsung dan tidak membosankan; pembelajaran disertai dengan pengamatan atau eksperimen juga lebih memudahkan siswa untuk memahami materi tersebut.

Pada proses pembelajaran IPA berbasis pendekatan saintifik dengan model pembelajaran inkuiri terbimbing, siswa dibagi menjadi beberapa kelompok untuk berdiskusi dan melakukan pengamatan sehingga kesempatan untuk bekerja sama sangat besar; 3 siswa sangat setuju dan 19 siswa setuju (kelas VII-A), dan 21 siswa kelas VII-B setuju bahwa soal-soal lebih mudah diselesaikan dalam proses pembelajaran saintifik, karena pembelajaran tersebut terdiri dari beberapa tingkatan fase yang dapat mengkonstruksi konsep siswa sesuai teori Piaget, dalam kelompok siswa dapat saling bertukar berpendapat tentang konsep yang mereka pahami, dengan adanya proses scaffolding maka siswa mampu menyelesaikan permasalahan yang ada sehingga dapat meningkatkan penguasaan konsepnya (Nur, 2011).

Berdasarkan semua aspek angket respon siswa di kelas VII-A dan VII-B, diperoleh nilai rata-rata masingmasing sebesar 3,3 dan 3,4 dengan kategori setuju. Dapat disimpulkan bahwa siswa memberikan respon yang baik terhadap pembelajaran IPA berbasis pendekatan saintifik dengan model pembelajaran inkuiri terbimbing. Respon yang baik terhadap pelajaran tertentu akan meningkatkan minat belajar 
siswa sehingga mempengaruhi tuntas atau tidaknya hasil belajar siswa dalam proses pembelajaran. Hasil penelitian yang relevan adalah penelitian yang dilakukan oleh Hidayati (2014) yang menyatakan bahwa respon siswa pada pendekatan ilmiah tinggi (baik).

\section{KESIMPULAN}

Mengacu pada tujuan penelitian dan didukung dengan data hasil penelitian serta diikuti pembahasannya, maka dapat disimpulkan bahwa perangkat pembelajaran IPA berbasis pendekatan saintifik dengan model pembelajaran inkuiri terbimbing layak untuk digunakan

\section{REFERENSI}

Anonim. (2013). Konsep Pendekatan Saintifik. Jakarta: Kemendikbud.

Arends, R. (2008). Learning To Teach, Edisi Ketujuh. Yogyakarta: Pustaka Belajar.

Bilgin, I. (2009). "The effects of guided inquiry instruction incorporating a cooperative learning approach on university students' achievement of acid and bases concepts and attitude toward guided inquiry instruction". artikel diakses onlinehttp://www.acdemicjournals.org/sre. 11 April 2014.

Depdiknas. (2006). Panduan Pengembangan Pembelajaran IPA Terpadu Sekolah Menengah Pertama/ Madrasah Tsanawiyah (SMP/ MTs). Diakses online http://www.puskur.net.

Hidayati, N. (2014). "Pengaruh Pendekatan Ilmiah (Scientific Approach) dalam Pembelajaran
Terhadap Hasil Belajar Siswa Kelas XII TITL 1 SMK Negeri 7 Surabaya pada Standar Kompetensi Mengoperasikan Sistem Kendali Elektromagnetik. Jurnal Pendidikan Teknik Elektro”. Vol. 03 No. 02 Tahun 2014,25-29. Diakses

Online https://id.scribd.com/doc/222541393/. 3 Oktober 2014.

Kemdikbud, (2013). Pengembangan Kurikulum 2013 dan Paparan Mendikbud dalam Sosialisasi Kurikulum 2013. Jakarta: Kemdikbud.

Khoiroh, D. (2013). Pembelajaran Penemuan Terbimbing untuk Meningkatkan Penguasaan Konsep dan Keterampilan Brpikir Kritis Siswa pada Pokok Bahasan Asam, Basa, dan Garam di SMP. Makalah Komprehensif Program Pascasarjana Pendidikan Sains UNESA.

Machin, A. (2014). "Implementasi Pendekatan Saintifik, Penanaman Karakter, dan Konservasi pada Pembelajaran Materi Pertumbuhan". Jurnal Pendidikan IPA Indonesia JPII 3 (1) (2014) 28-35. Diakses online

http://journal.unnes.ac.id/nju/index.php/jpii. 3 Oktober 2014.

Nur, M. (2011). Model Pembelajaran Berdasarkan Masalah. Surabaya: PSMS UNESA.

Undang-Undang Republik Indonesia No. 20 Tahun 2003 tentang Sistem Pendidikan Nasional. Jakarta: Depdiknas. 